\title{
28. SUMMARY OF LEG 10, BIOSTRATIGRAPHY
}

\author{
Lee Anderson Smith, Esso Production Research Company, Houston, Texas, \\ and \\ Blake McNeely, Shell Oil Company, Metairie, Louisiana
}

\section{GENERAL}

From the standpoint of improving the quality of future biostratigraphic work, the most significant contributions of Leg 10 will be:

1) the recovery of pelagic sediments representing almost the entire Cenozoic - thirty-two of the forty-three defined planktonic foraminiferal zones are reported from the shipboard samples alone, and most of the zones are recorded from two to four core holes.

2) the recovery of well-preserved radiolarian assemblages from Upper Paleocene to Miocene sediments that, in much of the section for the first time, can be well dated in terms of the planktonic foraminiferal and calcareous nannofossil zonation schemes; and

3) the documentation of a much improved zonation scheme for use in Upper Miocene to Holocene pelagic sediments that has been adequately related to the standard European stages.

Five of the core holes $(86,94,95,96$, and 97$)$ penetrated the Upper Cretaceous to Recent section represented mainly by pelagic sediments. Although none of the sections is complete, most of the Upper Cretaceous and Cenozoic is represented in one or more of the five sections. Geographic locations of the sites and of the biostratigraphic correlation sections are shown in Figure 1. Biostratigraphic correlation of all the holes, except Hole 93, is shown in Figures 2 and 3.

Abundant well-preserved Tertiary Radiolaria were found at four of the twelve sites drilled, and isolated occurrences of poorly preserved Cretaceous Radiolaria, Early Campanian and Early Cenomanian, at one site each.

Two points of particular interest are the cooccurrence of all the Radiolaria, except the Early Cenomanian, with calcareous microfossils and the presence of well-preserved Radiolaria in the Early Eocene and Late Paleocene. While the concurrence of Radiolaria and calcareous microfossils in sediments of Miocene and Oligocene age is not so unusual, their cooccurrence and recovery in older sediments (i.e., Eocene and Paleocene) in a long sequence is probably unique.

Detailed work on this material should result in the correlation of the Eocene and Paleocene Radiolaria with the established foraminiferal and calcareous nannofossil zones, thus increasing the stratigraphic usefulness of siliceous plankton, especially for sections that do not contain calcareous forms.

A correlation chart showing the distribution of sediments representing the planktonic foraminiferal zones for all of the core holes drilled on Leg 10 is presented in Figure 4. Indication is given on the chart as to the recovery of planktonic foraminiferal, calcareous nannofossil, and radiolarian assemblages for each of the planktonic zones. The chart is designed not only to summarize the planktonic zonal stratigraphy for all sections penetrated, but also to assist subsequent workers in selecting materials for study.

\section{ZONATION AND BOUNDARIES}

We have attempted consistently to use (or relate to) the "time-stratigraphic framework" and planktonic foraminiferal zonation scheme-essentially that of Walter Blow, both published and unpublished-as suggested in the Core Description Manual (JOIDES, 1968). There are, however, several difficulties with their rigorous application.

The European Stages, as defined, do not represent the whole of geologic history - that is, they do not form the continuum of record artificially imposed on them in the JOIDES "time-stratigraphic framework." The European Stages do furnish anchor points (partial records), within the time-stratigraphic framework, that should be taken into consideration when assessing the relative ages of sediments elsewhere. We are not, however, certain of the age relationships, in several instances, between stages stratotypified in diverse regions. Therefore it is believed that our primary role is the testing and improvement of the biostratigraphic framework as represented by the various plankton-based zonation schemes. If, for example, the planktonic foraminifera-based zonation first is sound (uniformly applicable within their facies), a considerable contribution can be made to our knowledge of the stages, the relationships among them, and the positioning of the biostratigraphic framework with reference to them. In such case, the primary concern should be the biostratigraphic framework of reality rather than the time-stratigraphic framework of arbitration.

Published calcareous nannofossil zonation schemes have not been adequately tested and their relationships to planktonic foraminiferal zones are not sufficiently documented. A zonation developed and tested at Esso Production Research Company was employed here, but it is not available for publication at the present time. Since, however, it is very closely tied to the planktonic foraminiferal zonal scheme (essentially that of Bolli, 1957, 1966), calcareous nannofossil dating is in terms of planktonic foraminiferal zonal equivalency for all shipboard work. For the Late Neogene (Smith and Beard, laboratory studies, this volume), published calcareous nannofossil zones, as defined (Gartner, 1969; Martini, 1971), are applied to sections closely tied to the planktonic foraminiferal zones of Lamb and Beard (1971).

An attempt is made, in the following paragraphs, to explain difficulties encountered, conventions followed, 


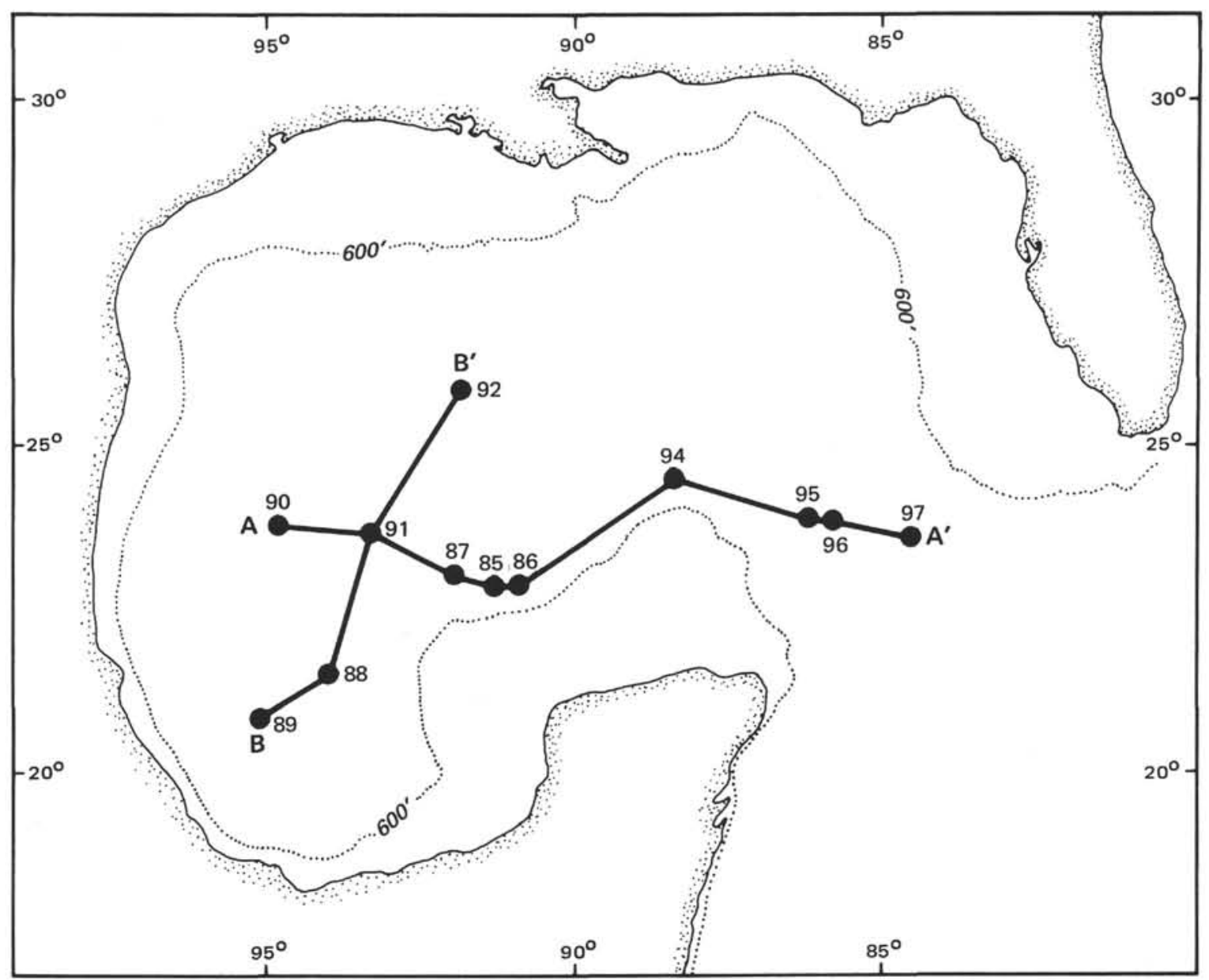

Figure 1. Leg 10 Site locations and biostratigraphic cross sections.

and improvements introduced which hopefully will be of value in future Deep Sea Drilling work as well as for biostratigraphy in general.

\section{The Cretaceous-Eocene Zonation}

Although we always attempted to follow the planktonic foraminiferal zones suggested in the JOIDES Core Description Manual, we must confess the actual use, for a shipboard manual, of Postuma's compilation for Shell Oil (1964). It is realized that it is a compilation (predominantly the works of Hans Bolli) and that technically it had not been published at the time of the cruise. On the other hand: (a) it is a relatively concise guide, more uniformly applicable for the part of the section it covered (1964 version-Cretaceous through Eocene); (b) it has been widely distributed by Shell, at least among academic institutions; and (c) it has now been published (Postuma, 1971).

\section{The Cretaceous-Tertiary Boundary}

For purposes of this report (and most others) Danian age sediments are considered to be basal Cenozoic rather than in limbo. Blow's P. 1 Zone is referred to as "Danian" and equivalent to the Early Paleocene. Therefore, the "Lower Paleocene, Montian" could not be employed.

\section{The Paleocene-Eocene Boundary}

The Paleocene-Eocene boundary, as defined on the earliest occurrence of Pseudohastigerina wilcoxensis, seems not to be consistent. Therefore, the boundary actually was picked between the Globorotalia velascoensis and Globorotalia rex ( $=G$. subbotinae) Zones of Bolli (1966). The Paleocene-Eocene boundary, so defined, seems to fall within Blow's P. 6 Zone and we correlate it with the suggested JOIDES zonation scheme in that way (Hole 94). In Hole 96, where Blow's P. 6 Zone could not readily be defined, the Paleocene-Eocene boundary is actually shown as between the $G$. velascoensis and $G$. rex Zones.

\section{The Eocene-Oligocene Boundary and Oligocene Zones}

The zonation of Bolli (1966) was used for recognition of the Eocene-Oligocene boundary (as falling between the Globorotalia cerroazulensis and Cassigerinella chipolensisPseudohastigerina micra Zones) and to a great extent for subdividing the Oligocene sediments. This zonation was related to Blow's zones in the biostratigraphic summaries. Biostratigraphy of the thick section of Oligocene sediments penetrated in Hole 95, containing the subspecies Globorotalia opima opima, suggests, but does not demonstrate, that Blow's assessment of the extended earlier range of that form may be correct. 
A

E

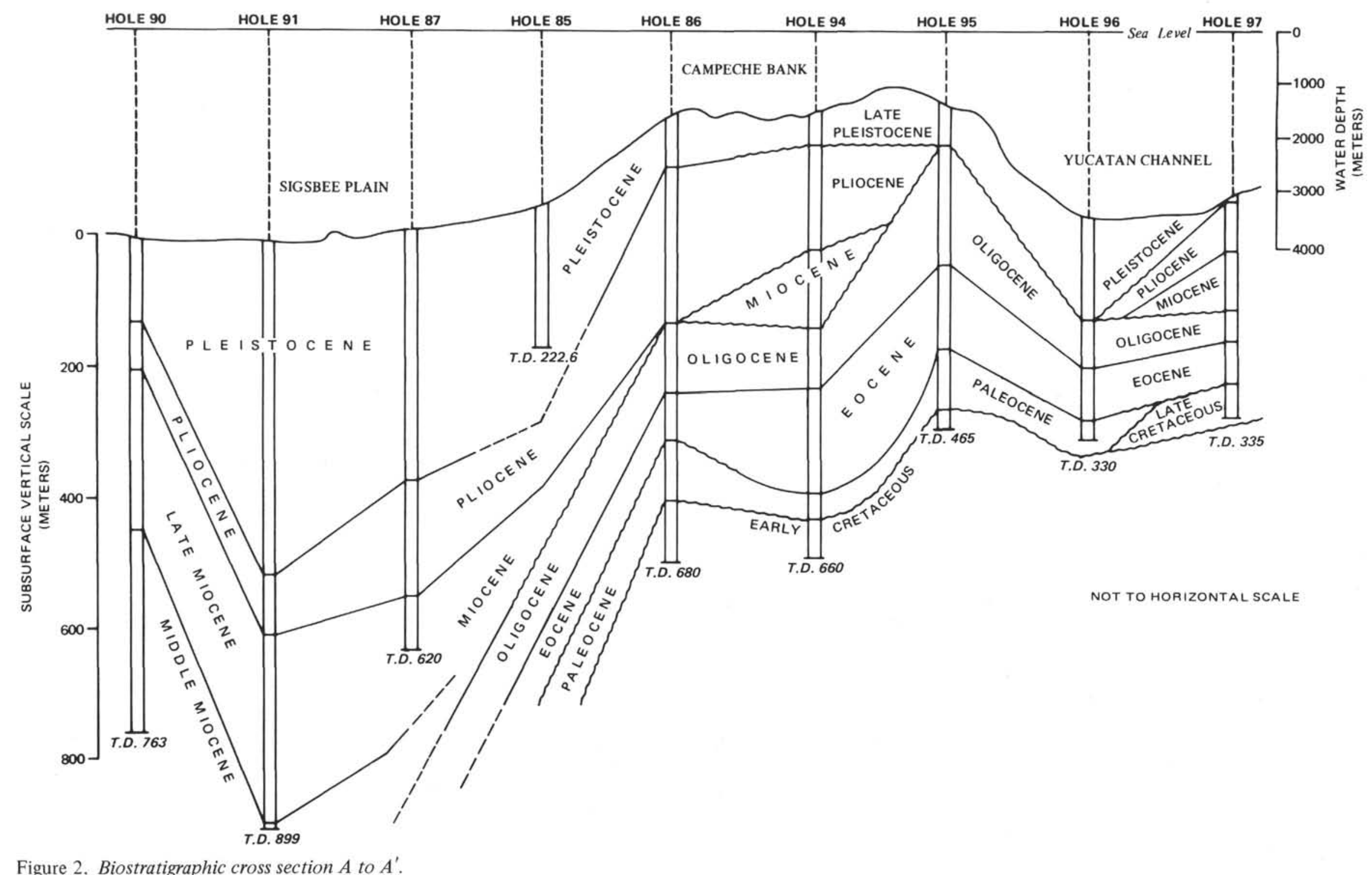

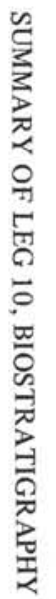

Figure 2. Biostratigraphic cross section $A$ to $A^{\prime}$. 
B

$\mathrm{B}^{\prime}$

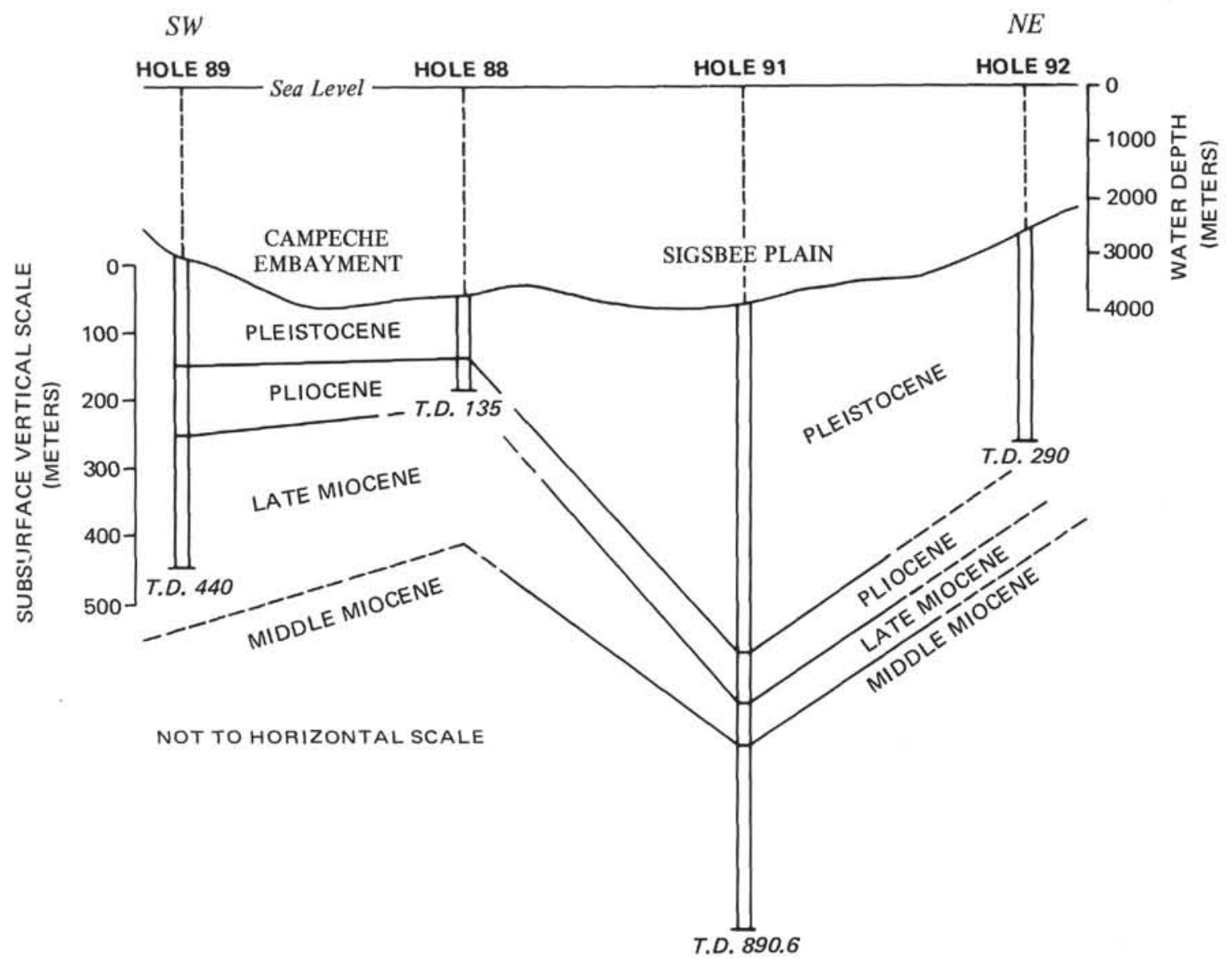

Figure 3. Biostratigraphic cross section $B$ to $B^{\prime}$.

\section{The Oligocene-Miocene Boundary and Early Neogene Zones}

The Oligocene-Miocene boundary was placed between the Globorotalia kugleri and Catapsydrax dissimilis Zones of Bolli (1966). For the most part, Bolli (1966) was followed for zonation of Lower and Middle Miocene sediments, but the appearance of Orbulina suturalis was used to mark the base of Middle Miocene and Blow's N. 9 Zone was found to be more useful than Bolli's Globorotalia fohsi barisanensis Zone.

\section{The Late Neogene Zonation}

Considerable difficulty was encountered attempting to apply Blow's zonation of the Late Neogene (Middle Miocene to Holocene). Actually that developed at Esso Production Research Company was used and it was attempted (somewhat unsuccessfully) to relate it to Blow's zonation, for purposes of shipboard communication. We are deeply indebted to Esso Production Research Company for releasing the Late Neogene zonation for publication (Lamb and Beard, 1971) in order that we might demonstrate its utility through application in the study of Leg 10 cores.

The Late Neogene zones used are defined briefly in a paper by Smith and Beard in this volume. A full description and documentation of the zones, as well as stereoscan illustrations of the most useful and widely distributed planktonic foraminiferal species, has been published by Lamb and Beard (1971).

The utility of the Esso zonation is documented (Lamb and Beard, 1971) using Gulf of Mexico Slope core hole material taken cooperatively by Humble, Chevron, Gulf, and Mobil. Its applicability is amply demonstrated in this volume.

\section{The Middle Miocene-Late Miocene Boundary}

The top of the Middle Miocene was taken to be contiguous with the top of the Globorotalia menardii Zone (Stainforth, 1948; Brönnimann, 1951; Bolli and Bermúdez, 1965, and Bolli, 1966). The base of Upper Miocene sediments was recognized on the appearance of Globorotalia acostaensis. Since $G$. acostaensis is reportedly found within 10 meters of the base of the Tortonian, this, as nearly as is consistently possible, includes the Tortonian in Late Miocene.

\section{The Miocene-Pliocene Boundary}

The base of the Pliocene was recognized on the appearance of Globorotalia margaritae, (base of the G. margaritae Zone of Bolli and Bermúdez, 1965).

\section{The Pliocene-Pleistocene Boundary}

The Pliocene-Pleistocene boundary was recognized on the extinction of Globoquadrina altispira, (top of the Pul- 


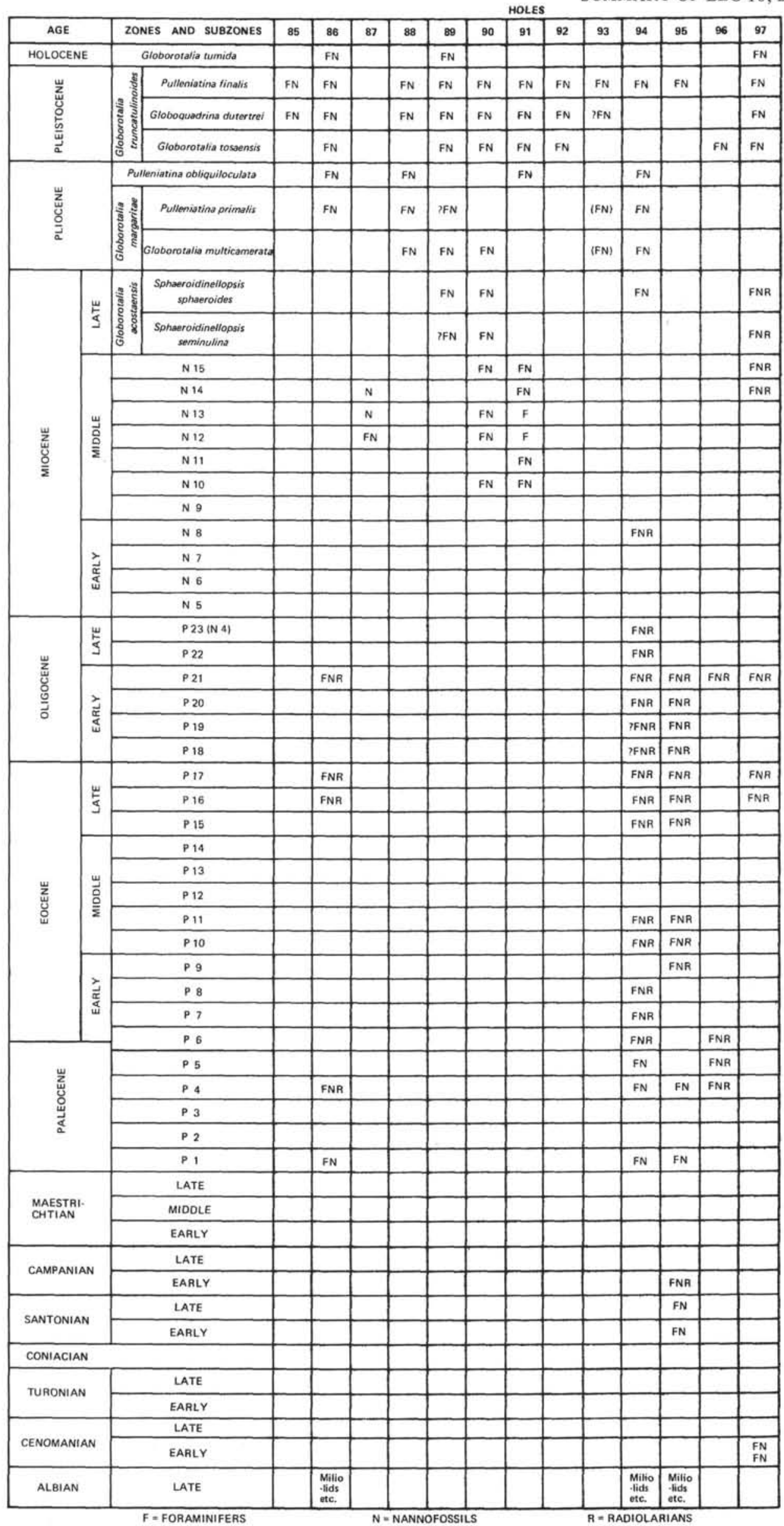

Figure 4. Planktonic zonal equivalency and age of all samples examined in shipboard work. 
leniatina obliquiloculata Zone of Lamb and Beard, 1971). This has been shown (Beard and Lamb, 1968; Beard, 1969; Lamb, 1969, 1971; and Smith, 1969) to correspond to the basal sediments of the stratotypical Calabrian of Italy. The solution is discussed more fully under "Laboratory Studies" (Smith and Beard, this volume), but, in essence, revolves around the use by other authors of the first abundant occurrence of Globorotalia truncatulinoides (rather than its appearance) for the base of the Pleistocene in deep sea sediments.

Since, as is amply demonstrated in this volume, Globorotalia truncatulinoides and the discoasters occur together in deep sea sediments (as well as in the stratotype Calabrian), there can be little doubt of the Pleistocene age of sediments well below the disappearance of discoasters and the first abundant occurrence of $G$. truncatulinoides.

The zonation scheme of Lamb and Beard (1971) is used in conjunction with calcareous nannofossil occurrences and paleoclimatic variation to subdivide the Pleistocene into the North American glacial-interglacial stages.

\section{The Pleistocene-Holocene Boundary}

The Pleistocent-Holocene boundary was recognized on the first abundant occurrence of large Globorotalia tumida and the final withdrawal from the Gulf of Mexico of colder water species such as Globorotalia inflata (7,000 to 11,000 years B.P.).

It is hoped that the Late Miocene to Holocene zonation of Lamb and Beard (1971), used as standard for Leg 10, will be tested and accepted by other workers. It is believed that it is a considerable improvement over existing zonation schemes and will aid significantly in the quest for uniformity of biostratigraphic application in this and future studies.

\section{REFERENCES}

Beard, J.H., 1969. Pleistocene paleotemperature record-planktonic foraminifers, Gulf of Mexico. Trans. Gulf Coast Assoc. Geol. Soc. 19, 537.
Beard, J.H. and Lamb, J.L., 1968. The lower limit of the Pliocene and Pleistocene in the Caribbean and Gulf of Mexico. Trans. Gulf Coast Assoc. Geol. Soc. 18, 174.

Bolli, H.M., 1957. Planktonic foraminifera from the OligoceneMiocene Cipero and Lengua Formations of Trinidad, B.W.I. U.S. Natl. Mus. Bull. 215, 97. 1966. Zonation of Cretaceous to Pliocene marine sediments based on planktonic foraminifera. Bolit. Inform. 9, 3.

Bolli, H.M. and Bermudez, P.J., 1965. Zonation based on planktonic foraminifera of middle Miocene to Pliocene warmwater sediments. Bolit. Inform. 8, 119.

Brönnimann, P., 1951. Globigerinita naparimaensis n. gen., n. sp., from the Miocene of Trinidad, B.W.I. Contrib. Cushman Found. Foram. Res. 2, 16.

Gartner, S., Jr., 1969. Correlation of Neogene planktonic foraminifer and calcareous nannofossil zones. Trans. Gulf Coast Assoc. Geol. Soc. 19, 585.

JOIDES, 1968. Core Description Manual-Part VII; Biostratigraphy. Deep Sea Drilling Project, 2 vols.

Lamb, J.L., 1969. Planktonic foraminiferal datums and late Neogene epoch boundaries in the Mediterranean, Caribbean, and Gulf of Mexico. Trans Gulf Coast Assoc. Geol. Soc. 19, 559. 1971. Planktonic foraminiferal biostratigraphy and paleomagnetics of the Late Pliocene and Early Pleistocene strata at Le Castella, Italy. Trans. Gulf Coast Assoc. Geol. Soc. 21, 411.

Lamb, J.L. and Beard, J.H., 1971. Late Neogene planktonic foraminiferal zonation. Univ. Kansas Paleo. Contrib., Harold Norman Fisk Mem. Papers.

Martini, E., 1971. Standard Tertiary calcareous nannoplankton zonation. In Proc. II Plankt. Conf., Roma. A. Farninacci (Ed.). Rome (Tecnoscienza).

Postuma, J.A., 1964. Manual of Planktonic foraminifera: Unpublished Shell Rept. The Hague (Bataafse Internationale Petroleum Maatschappi) 2 vols. $420 \mathrm{p}$.

Smith, L.A., 1969. Pleistocene discoasters from the stratotype of the Calabrian Stage (Santa Maria di Catanzaro) and the section at Le Castella, Italy. Trans. Gulf Coast Assoc. Geol. Soc. 19, 579.

Stainforth, R.M., 1948. Description, correlation and paleoecology of Tertiary Cipero Marl Formation, Trinidad, B.W.I. Bull. Am. Assoc. Petrol. Geologists. 32, 1292. 